International Journal of Advanced Academic Studies 2021; 3(1): 412-418

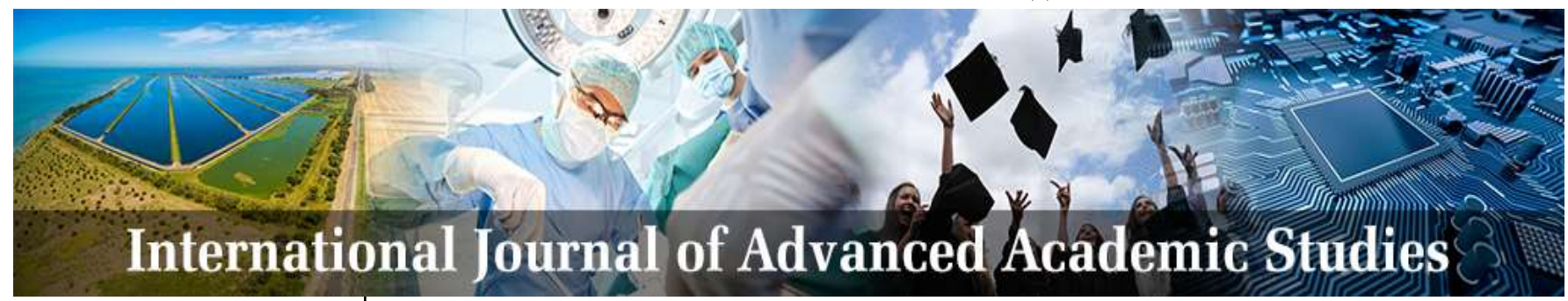

E-ISSN: 2706-8927

P-ISSN: 2706-8919

www.allstudyjournal.com

IJAAS 2021; 3(1): 412-418

Received: 03-11-2020

Accepted: 07-12-2020

Mohammad Salim Salim PH. D Student in State

Islamic University Sunan Kalijaga Yogyakarta,

Indonesia

Dr. Abdul Qoyum

SEI, M.Sc. Fin Faculty of

Islamic Economy State Islamic

University Sunan Kalijaga

Yogyakarta, Indonesia

\section{Factors delaying the establishment of the Islamic banking system in Afghanistan}

\author{
Mohammad Salim Salim and Dr. Abdul Qoyum
}

DOI: https://doi.org/10.33545/27068919.2021.v3.i1f.515

\begin{abstract}
According to some economical politicians of the world, Islamic scholars and the mental state of most Muslims who have a moderate economy, existence of Islamic banking considered an important issue. After the downturn of the economy of the world several economical politicians, even Vatican pointed out; that the Islamic banking could be an alternative for the existing economic system. According to Afghan Islamic scholars and some Afghan merchants, Afghanistan is a pour country. But due to some factors it has been founded so late in Afghanistan. The basic rolls of Islamic economic have solutions for the poverty. Afghanistan is an Islamic state, and almost all residents are Muslim. $90 \%$ of the people do not use conventional banks due to religious orders in Afghanistan. But Islamic Banking system was founded so late compared to other countries. There are some factors caused late establishment of Islamic Banking system in Afghanistan. These factors will be discussed in this paper.
\end{abstract}

Keywords: Late establishment, Islamic Banking, Afghanistan

\section{Introductions}

This paper is about the most important phenomenon (founding Islamic Banking) which had to be founded very early in Afghanistan but it was created so late. Because According to $2^{\text {nd }}$ article of the first constitution of Afghanistan after British colonization, the official religion of Afghanistan is Islam ${ }^{[1]}$. After that 7 mor constitutions were made in Afghanistan in (1931 $-1964-1977-1979-1980-1992-2003)^{[2]}$. In fife of these constitutions we can see the same thing (the official religion of Afghanistan is Islam). More than that, in last two constitutions Afghanistan is introduced as an Islamic state (Islamic Republic of Afghanistan). According to the (ACCI) $90 \%$ of residents of Afghanistan are denying from dealing with conventional banks due to religious believes, because of the interest ${ }^{[3]}$. But in 2004 Bank Mili Afghanistan, in 2005 Bank Alfalah Ltd which is nun-Afghan Bank, in 2007 Afghan United Bank, in 2008 Maiwand Bank, in 2009 Ghzanfar Bank, and in 2011 New Kabul Bank opened Islamic Banking windows. Finally, the first full flagged Islamic bank under the title of Islamic Bank of Afghanistan was established in Afghanistan in 2018 [4]. Which seems to be very late compared to other majority Muslim population countries. For example, In 1997 Islamic banking system was adopted in 50 states ${ }^{[5]}$. Da Afghanistan bank (the central bank of Afghanistan) in December 18/2019 officially announced, that it will provide Islamic banking services ${ }^{[6]}$. The central bank of Afghanistan issued its shariah framework in December 2019 under the title of: Shariah Compliant Banking-National Shariah Governance Framework "Full-Fledged IFI version" [7].

Existing of Islamic banking system is needed seriously. The idea of Islamic banking could have longer history but after the economic crises of the world it has become a significant issue.

\footnotetext{
1 (Nezam Name Asaasi Dawlat Alaihe Afghanistan (Constitution), 1340 AH تاريخ جك شود)

2 "Sair Tarikhi Qanone Asaasi Afghaniatan (History of Constitution of Afghanistan)," accessed July 5, 2020, http://www.afghan-german.net/upload/elmi_bibliothek/history_afg_constitutions_dari.pdf.

3 ACCI, "Bank Dary Dar Afghanistan Da Yak Daha Wa Door Namaiaan (Banking In Afghanistan And Its Forground)," March 20, 2012, file:///E:/AFGHN-BANKING/Banking Booklet (2).pdf.

4 DeAfghanistanBank, "Da Afghanistan Bank Issued Its First Islamic Banking License" (Kabul, 2018), https://dab.gov.af/da-afghanistan-bank-issued-its-first-islamic-banking-license.

${ }^{5}$ Abdel K. Halabi Ashraf U. Kazi, "The Influence of Quran and Islamic Financial Transactions and Banking," Brill

20, No. 3 (2006): 12, https://about.jstor.org/terms

${ }^{6}$ (Radio Azhadi, n.d.)

${ }^{7}$ (Regulation on Islamic Banking Liquidity Risk Management, 2018.)
}

Corresponding Author: Mohammad Salim Salim University Sunan kalijaga Yogyakarta, Indonesia 
The people around the world are suffering from losing their money and looking for an alternative for the existing economics arrangements. Some economists and social liders believe that Islamic banking could be a good alternative ${ }^{[8]}$. L'Osservatore Romano, the Vatican newspaper and tacit mouthpiece of the pope, wrote that the "principles on which Islamic finance is based may bring banks closer to their clients and to the true spirit which should mark every financial service" [9]. Islamic Banking is strongly needed in Afghanistan because Afghanistan is one of the poorest countries in the world and Islamic Banking system has some solution for the poverty, told Saeed Habibullah former administrative director of the ministry of Guidance, Hajj and Endowments in the interview ${ }^{[10]}$.

This article will discuss some of the problems in front of Islamic Banking in Afghanistan. Some of these problems are related to economics, and some to Islamic schoolers, and some to luck of laws and regulations. This research is very important and useful for Islamic society spatially for Afghans, because if the factors which let Islamic banking to be late, still exist, this study will help, to solve or omit them.

\section{Methodology}

This research is trying to find reasons of late establishment of Islamic banking in Afghanistan, by analyzing literatures that the writer was able to find them and some interviews with the people who are involved in Islamic law and economics in Afghanistan. This paper is mostly standing on online materials. The materials that are used in this paper are primary and secondary sources, like interviews, Afghan Banks' reports, World Bank's reports, historical books, articles that are published in international journals, newspapers, international radios and TVs. The writer categorized all the literatures and interviews according to the issues which caused late establishment of Islamic Banking in Afghanistan. After that he analyzed them and wrote the outcome of the analyzation in the place that he wanted according to structure of this paper.

\section{Research question}

why in the country in which almost all are Muslim, and the most of them do not use conventional banks, Islamic banking system started so late then other Muslim majority countries like Indonesia, Pakistan, Iran and so on, and even later than some Non-Muslim majority countries like UK, and the USA and so on? This research will try to find the causes of non-establishment of Islamic banking earlier in Afghanistan.

\section{Literature review}

Islamic economics and Banking could go ahead side by side of the devilment of the modern human society. Some anthropological literatures shou that Islamic shariah and Islamic economic is a way or a stile of the human's life. Sharia in the West is known to be medieval and out of date: that ought to be feared and despised. But the reality is something else. Sharia is a set of main points for moral

\footnotetext{
8 Rudnyckyj Daromir, Beyond Debt, Islamic Experiments in Global Finance (Chicago: The University of Chicago Press, 2019),

https://books.google.co.id/books/about/Beyond_Debt.html?id=3g1uDwAA QBAJ\&printsec $=$ frontcover\&source $=$ kp_read_button\&redir_esc $=\mathrm{y} \# \mathrm{v}=$ one page \&q\&f=true.

${ }^{9}$ Daromir.

${ }^{10}$ Saeed Habiobullah, "Interview," 2020.
}

conducts and ethics of daily life for Muslims. It is highly informative and flexible. Sharia is a process of knowledge which a Muslims use it when facing any challenges of his or her life ${ }^{[11]}$. Daromir Rudnyckyj says that Islamic Banking could be a good replacement for the conventional existing banking system which caused the global economic crises ${ }^{[12,}$ 13].

Islamic banking system is still at its early stages compared to the conventional banking system which existed about 600 years ago ${ }^{[14]}$. The oldest continually operating bank in the world is Banca Monte dei Paschi di Siena, which has been operating as a bank in Italy since $1472^{[15]}$. Many Islamic banks grew in deferent countries in 1970s and the next. By the early 1980s. Islamic banks have also emerged in nonMuslim countries like Europe, America, and Australia ${ }^{[16]}$.

The central bank of Afghanistan 'de-Afghanistan Bank' issued its shariah framework in December 2019 under the title of: Shariah Compliant Banking-National Shariah Governance Framework 'Full-Fledged IFI version' [17]. Samangani Aliakbar Sadeqi says that before some decades Islamic banks rarely were operating in the world. $\mathrm{He}$ is talking about banking system generally and saying that: the banking system in Afghanistan is too weak, and Afghanistan should open Islamic banking system ${ }^{[18]}$. Islamic Banking is a book, which is written by Mohammad Anwar Kohestany, he is talking about Islamic banking generally not about Islamic banking in Afghanistan. This book is published in 2017 by Amin digital Library in Afghanistan ${ }^{[19]}$. There is a booklet published by Afghanistan chamber of commerce \& industries ' تاق تجارت و صنايع ' 'banking in Afghanistan in last 10 years and its overview' in 2012. There is a short list of some branches providing Islamic banking services and reports of banking in last 10 years and there are some propose in this booklet [20]. International Islamic University Malaysia published an article under the title "the viability of islamic banks under the current legal framework of afghanistan, djibouti, kuwait and sri lanka" written by Ahmad Alrazin and Abdullah Ludeen. There is a very short information about Islamic banking in Afghanistan, in this article. The authors of this article are saying that in the concept of Islamic financial system could not accept or use interest-based system which is used currently in Afghanistan. Islamic financial system will be a new system and an alien term for some people where the people do not know the system, or they do not have enough information about Islamic financial system.

\footnotetext{
${ }^{11}$ Sarah A. Tobin, Everyday Piety Islam And Economy In Jordan (Ithaca And London: Cornell University Press, 2016).

${ }^{12}$ Rudnyckyj, Beyond Debt Islamic Experiments in Global Finance.

13 Robert W. Hefner, Islamizing Capitalism: On the Founding of Indonesia's First Islamic Bank, ed. Azyumardi Azra Arskal Salim (ISEASYusof Ishak institute, n.d.).

${ }_{14}$ Zahri Hamat3 Mutiara Dwi Sari1, *, Zakaria Bahari2, "History of Islamic Bank in Indonesia: Issues Behind Its Establishment," International Journal of Finance and Banking Research 2 (2016): 178-84.

$15 \mathrm{Https} / / / \mathrm{www}$.reference.com/history/first-bank-world-ce6f0b48dce882c3, "What Was the First Bank in the World?," accessed August 7, 2020, https://www.reference.com/history/first-bank-world-ce6f0b48dce882c3.

16 Mutiara Dwi Sari1, *, Zakaria Bahari2, "History of Islamic Bank in Indonesia: Issues Behind Its Establishment."

${ }^{17}$ DAB, Regulation on Islamic Banking Liquidity Risk Management.

${ }^{18}$ Samangani, "Bankdari Bedoon Reba (Don Yosury Banking)."

19 Dr. MohammadAnwar Kohstani, Nzam Bankdari (Banking System) (Kabul: Amin alectronic laibrary, 2017), file:///E:/AFGHNBANKING/نظام-بانكدارى-4.محمد-انوركو هستنان.pdf.

${ }^{20}$ ACCI, "Bank Dary Dar Afghanistan Da Yak Daha Wa Door Namaiaan (Banking In Afghanistan And Its Forground)."
} 
The writers also tilling that in Afghanistan will be lots of challenges and limitations for implementation of Islamic financial system ${ }^{[21]}$. Growth and future of Islamic banking in Afghanistan is a 'post-graduate dissertation' written by Mohammad Haroon Amiri published by Coventry University in 2013. There are five chapter in it within 49 pages. Chapter 1 . Introduction to the study, chapter 2. The literature review 3. Research plan 4. Data collection, analysis, and findings and 5. Conclusion and recommendation. As it is seemed, it is concluded in 49 pages including cover pages and tables of contents, so there is very short and limited information. The writer listed some issues and challenges that Islamic banks will face ${ }^{[22]}$.

\section{Findings and discussion}

By analyzing of literatures, I found that Islamic Banking system has been needed for a long time in Afghanistan, but due to some factors it was founded so late and still it is not strong enough.

a. Islamic Banking system has been needed for a long time in Afghanistan: First, according to economic pollinations there should be an alternative for the conventional banking system which has been existing for a long time and caused the world's economic downturn ${ }^{[23]}$. Islamic banking could be an alternative. In the west, the people think that Islam is just prayers and violence and there is nothing for the live and society, but the reality is not like this. In reality, Islam is a collection of moral conduct and ethics of daily life for the life. It is very flexible and interpretive. Islamic Sharia is a procedure of knowledge farming that Muslims use it when facing the challenges of the daily life ${ }^{[24]}$. L'Osservatore Romano, the Vatican newspaper and tacit mouthpiece of the pope, wrote that the "principles on which Islamic finance is based, may bring banks closer to their clients and to the true spirit which should mark every financial service" ${ }^{[25]}$ Islamic Sharia especially Islamic economic could help the government and the society to go forward and create a kind of equality in the society ${ }^{[26]}$. During the world economic crises the people were suffering from losing their many and wanted and looking for a solution. Islamic economic palpitations are arguing that Islamic economics is a good alternative and solution ${ }^{[27]}$. Now coming to Afghanistan, almost all the people how are living in Afghanistan are Muslim, the government is Islamic "Islamic Republic of Afghanistan" ${ }^{28]}$. and 90\% of the people do not use Banks duo to religious orders, ${ }^{[29]}$. so the Islamic banking and economy is a necessary object, but there are some factors led Islamic banking to be founded so late and they are as fallowing.

\footnotetext{
${ }^{21}$ Al-Shammari and Ludeen, "The Viability Of Islamic Banks Under The Current Legal Framework Of Afghanistan, Djibouti, Kuwait And Sri Lanka."

${ }^{22}$ Mohammad Haroon Amiri, "Growth and Futute of Islamic Banking in Afghanistan."

${ }^{23}$ Daromir, Beyond Debt, Islamic Experiments in Global Finance.

${ }^{24}$ Tobin, Everyday Piety Islam And Economy In Jordan.

${ }^{25}$ Daromir, Beyond Debt, Islamic Experiments in Global Finance.

${ }^{26}$ Hefner, Islamizing Capitalism: On the Founding of Indonesia's First Islamic Bank.

${ }^{27}$ Daromir, Beyond Debt, Islamic Experiments in Global Finance.

${ }_{28}$ constitution.

29 ACCI, "Afghanistan Chamber of Commerce \& Investment," ACCI, 1396, https://www.acci.org.af/da/home/38-news/1216-n.html.
}

b. Political instability: Tow first decades and last four decades of Twentieth century were full of war and invades. Afghanistan is a country that never experienced transfers of the power from one to another by the power of the people. Political currents have been changing for the last hundred years which during these years, Afghanistan has been changed from kingdom to republic and from republic to the People's Democratic Republic of Afghanistan, and from radical to Islamic Republic of Afghanistan, and from Islamic Republic of Afghanistan, to Islamic Emirate and from Islamic emirate to Islamic Republic. But all of these changes did not seem to be the transfer of power by voting of the people. The systems have always changed by coups and pressures of foreign states ${ }^{[30,31,32,33]}$. Mohammad Haroon Amiri also found by questioner that political instability is a challenge for Islamic banking system. ${ }^{34}$ Haji Amanullah the head and owner of Resalat Travel Company said in the interview: "...because of the political influences of foreign countries on the Afghan government, sometimes former Soviet Union and sometimes USA and western countries, the creation of Islamic Banking was delayed" ${ }^{[35]}$. Abdullah Mohammedi former general director of Afghan United Bank told: "In $1357 \mathrm{AH}$, the communist party mad revolution the private sector was not allowed to make banks and the national banks were under the control of former Soviet Union, and after the communist regime the civil war was started, so the investors did not wanted to put their money in danger ${ }^{[36]}$. As it is mentioned above, the political situation was shaken for almost 100 years. All the people worried about their life and security, so they did not have chances or time to think about the money and the way of its investing and the banking system. That is way Islamic banking system was not established earlier.

c. Weak economy: Because of the ware and geographical situation of Afghanistan the government and individuals had weak economy. The exports of Afghanistan in 2009 was 549 million US\$, and it was ranked as $164^{\text {th }}$ country in the world [37]. Due to the report of world bank which is published in (8 O'clock of Morning) knows paper Kabul Afghanistan, Afghanistan is ranked as $183^{\text {rd }}$ in $2017^{[38]}$. A questioner which was distributed for 100 people by Mohammad Haroon Amiri, shows that insufficient investment capacity is a challenge for creating Islamic banks ${ }^{[39]}$.

\footnotetext{
${ }^{30}$ Fofalzaie, Negahe Ba Tarikh Hsterdad Hstqlal (A Look at the History of Independence).

${ }^{31}$ Mirghulam Mohammad ghubar, Afghanistan Dar Masir Tarikh.

32 Abdulwali SDiqi, "Az Amanullahta HmedKarzay," Shabake Atlaa Rasani Afghanistan (Afghanpaper.Com, no. shabake Atlaa rasani Afghanistan (Afghanpaper.com (1392), http://www.afghanpaper.com/nbody.php?id=63679.

${ }^{33}$ BBC, "Afghanistan's Ghani Says 45,000 Security Personnel Killed since 2014."

${ }^{34}$ Mohammad Haroon Amiri, "Growth and Futute of Islamic Banking in Afghanistan."

35 (Haji, Uga25/ 20202)

${ }^{36}$ Abdullha Mohammadi, "Interviow" (Kabul, 2020).

37 "Aqtsad Afghanistan," n.d.

38 ، 8 Subh, 1396 Sartan.

${ }^{39}$ Mohammad Haroon Amiri, "Growth and Futute of Islamic Banking in Afghanistan."
} 
There are some reasons that caused weakness of the economy of Afghanistan, and they are:1) Misunderstanding of Islam 2) Ignores 3) Being fascist 4) Laziness 5) Being naughty 6) Lack of hiring the right person on the Jab. 7) External interventions. 8) Foreign offices ${ }^{[40,41]}$. In conclusion there was not enough money to invest on Islamic banks and the individuals also did not have enough money to save it in Islamic banks or gave it to Islamic banks.

d. Lack of legislative support: The legislative body of the government always has been under the pressure of the war and politics, on the other hand they did not have any information about banking and Islamic law, so we cannot see any law about Islamic banking. Ahmad Alrazni and Abdullah Ludeen say: it is very important for a country with almost all Muslim nation like Afghanistan, to have full-fledged Islamic banking system, but Da Afghanistan bank must pass Islamic banking law through parliamentary first, then issue licenses for full-fledge Islamic banking in the country [42]. According to Amiri lack of legislation and regulatory framework for Islamic banks, could be a chilling for Islamic banking sector ${ }^{[43]}$. Until now there is no separate an Islamic law, but only chapter seven (article 88 - 91) of Banking Law of Afghanistan is about Islamic Banking ${ }^{[44]}$. There are some regulations about Islamic Banking in De Afghanistan [45]. Hajji Amanullah said in the interview: that the effective laws of the country is one of the causes of late establishment of Islamic Banking in Afghanistan ${ }^{[46]}$. Us mentioned the legislative body of the government have not sported Islamic Banking system in Afghanistan, and that is another reason for late establishment of Islamic banking system in this country.

e. Lack of Ulama's support: The religious schoolers (Ulama) have a significant role on behavior of the people in Afghanistan, but the Ulama due to some reasons did not sport Islamic banking idea as strong as it was needed. Usually, the Ulama are studying in local mosques and privet Madrasas, and they are for from the modern way of life. Due to many reasons these Madrasas are in villages remotes. Tbian (تبيان) newspaper which was published in the year $1395 \mathrm{AH}-$ 2016 AD, published a report which says although there are 6000 Madrasas operating in Afghanistan, the ministry of education of Afghanistan says, that the ministry of education does not have any monitoring on 1300 Madrasas in Afghanistan. There is no sign of teaching political or any social content in these schools [47]. It means that these Madrasah do not follow the official curricula of the Ministry of education of

\footnotetext{
${ }^{40}$ SDiqi, "Az Amanullahta HmedKarzay.”

${ }^{41}$ Al-Shammari and Ludeen, "The Viability Of Islamic Banks Under The Current Legal Framework Of Afghanistan, Djibouti, Kuwait And Sri Lanka."

${ }^{42}$ Al-Shammari and Ludeen.

${ }^{43}$ Mohammad Haroon Amiri, "Growth and Futute of Islamic Banking in Afghanistan."

44 "Banking Law of Afghanistan" (n.d.), https://www.kakaradvocates.com/data/laws/Law on Banking of Afghanistan - En.pdf.

${ }^{45}$ De Afganistan Bank, "Islamic Banking Regulations (IBR)."

46 (Haji, 2020.)

${ }^{47}$ (Tebian, 2016.)
}

Afghanistan, and there is not anything about modern live to be learned, so the graduates do not know anything about modern economy and banking, to sport it. On the other hand, lack of sharia compliant technology and applications is also a chilling to create Islamic banking in Afghanistan ${ }^{[48]}$. Since the Madrasahs are located in rural areas and their curriculum is limited to classical Arabic books and there is no cine of other social sciences, the Ulama by themselves do not know about banking system, so how they can support the Islamic banking idea. That is why the religious schoolers and Ulama did not and could not support the idea of Islamic banking in Afghanistan.

f. Lack of public information: Many Individuals do not have enough information about banking system, and only $10 \%$ of the people have a bank account in Afghanistan ${ }^{[49]}$. Because of the war many schools are closed, and the economy of the families became down and they are not able to send their children to schools. UNESCO stayed in 2016, that approximately eleven million $11,000,000$ people are illiterate or with low level of education that they cannot read or write ${ }^{[50]}$. Millions of dollars have been spent on literacy in Afghanistan so far, but the country still has one of the lowest literacy levels in the world. According to the United Nations, about $80 \%$ percent of the women and $60 \%$ present of the men are illiterate. Vice of America VOA said in 2019: that the ministry of education of Afghanistan told that $42 \%$ of population of Afghanistan are illiterate and the majority are women ${ }^{[51]}$.

g. Lack of specialists in the field. Lack of specialists in the field and lack of awareness of the people in general is another problem Infront of Islamic Banking in the country. There are many governmental and privet universities in Afghanistan, but no-one has Islamic finance or Islamic economy or Islamic banking department ${ }^{[52]}$. professor Dr. Lutfurrahman Saeed former Deputy Chairman and the member of the Independent Commission for Implementation of the Constitution of Afghanistan told in the interview: one of the factors which caused late establishment of Islamic Banking in Afghanistan is lack of specialists in the field, till now we do not have them. On the other hand, hiring the foreign specialists are mor expensive. Even for conventional banks there are not enough experts in Afghanistan. Many the workers of DeAfghanistan bank are from Pakistan, told the hade of De-Afghanistan bank ${ }^{[53]}$. finally lack of educated specialists was the other chilling in front of creation of

\footnotetext{
${ }^{48}$ Mohammad Haroon Amiri, "Growth and Futute of Islamic Banking in Afghanistan."

${ }^{49}$ Nasir Behzad, “بانكدارى در افغانستان؛ ده درصد مردم حساب بانكى دارندOnly 10\% of the People in Afghanistan Have a Bank Account," BBC NEWS, 2020, https://www.bbc.com/persian/afghanistan-51082747.

${ }^{50}$ Husain Sirat, “حدود يازده ميليون افغان بىسوادندAbout 11 Million Afghans Are Illirerate."

51 VOA, “جمعيث باسو اد در افغانستان به بfthe Literari Popuation in Afghanistan $\quad$ Reached $42 \%$," https://www.darivoa.com/a/literacy-level-in-Afghanistan-rose-to-42percent/5074717.html.

52 Al-Shammari and Ludeen, "The Viability Of Islamic Banks Under The Current Legal Framework Of Afghanistan, Djibouti, Kuwait And Sri Lanka."

${ }^{53}$ Marzia Adeel, “بانك ،اسلامى' الفلاح در كابل آغاز به كار كرد Al-Fallah Islamic Bank Opened in Kabul.”
} 
Islamic Banking in Afghanistan and it is still a big chilling for growing this system in the country.

\section{h. Current situation and the way forward}

Although there is ware in Aghnistan. The poletical and social setuation is not so good, and securaty is not trastable, the banking system is good and groing up. Mr. Alhaj Khanjan Alokozai, First Deputy Chairman of the Board of Afghanistan Chamber of Commerce and Industries, says: Eave though there are series of problems facing the country's private sector, especially security challenges and banks' problems in the provinces; Afghanistan has progress and achievements in the field of international banking, including the withdrawal of Afghan banks from the blacklist and ease of money transfer ${ }^{[54]}$. Acording to De Afghanistan Bank (the sentral Bank of Afghnistan) There are 12 banks operating in Afghanistan consisting of 3 state-owned banks, 7 private banks and 2 branches of foreign banks ${ }^{[55]}$. Sex banks have windows for Islamic banking, and one is a fullfledged Islamic Bank. Short information is provided about everyone as following.

Table 1: foreign Bank which provides Islamic Banking services in Afghanistan ${ }^{[56]}$.

\begin{tabular}{|c|c|c|c|c|}
\hline $\begin{array}{c}\text { Name of } \\
\text { the bank }\end{array}$ & $\begin{array}{c}\text { Type of the } \\
\text { Bank }\end{array}$ & $\begin{array}{c}\text { License } \\
\text { Date }\end{array}$ & Website & SWIFT \\
\hline $\begin{array}{c}\text { Bank } \\
\text { Alfalah Ltd }\end{array}$ & $\begin{array}{c}\text { Branch of } \\
\text { Foreign } \\
\text { Bank }\end{array}$ & $\begin{array}{c}21 \text { May } \\
2005\end{array}$ & $\begin{array}{c}\text { www.bankalfala } \\
\text { h.com }\end{array}$ & ALFHAFKA \\
\hline
\end{tabular}

Table 2: Afghan private Banks which have Islamic banking windows ${ }^{[57]}$.

\begin{tabular}{|c|c|c|c|l|c|}
\hline No & $\begin{array}{c}\text { Name of } \\
\text { the bank }\end{array}$ & $\begin{array}{c}\text { Type of } \\
\text { the } \\
\text { Bank }\end{array}$ & $\begin{array}{c}\text { License } \\
\text { Date }\end{array}$ & Website & SWIFT \\
\hline 1 & $\begin{array}{c}\text { Afghan } \\
\text { United } \\
\text { Bank }\end{array}$ & $\begin{array}{c}\text { Private } \\
\text { Bank }\end{array}$ & $\begin{array}{c}4 \text { October } \\
2007\end{array}$ & www.afghanunitedbank.com Afguafka & Af \\
\hline 2 & $\begin{array}{c}\text { Maiwand } \\
\text { Bank }\end{array}$ & $\begin{array}{c}\text { Private } \\
\text { Bank }\end{array}$ & $\begin{array}{c}31 \\
\text { December } \\
2008\end{array}$ & www.maiwandbank.com & 0 \\
\hline 3 & $\begin{array}{c}\text { Ghazanfar } \\
\text { Bank. }\end{array}$ & $\begin{array}{c}\text { Private } \\
\text { Bank }\end{array}$ & $\begin{array}{c}1 \text { March } \\
2009\end{array}$ & www.ghazanfarbank.com & 0 \\
\hline
\end{tabular}

Table 3: Afghan state owned Banks which have Islamic banking windows ${ }^{[58]}$.

\begin{tabular}{|c|c|c|c|c|c|}
\hline No & $\begin{array}{c}\text { Name of } \\
\text { the bank }\end{array}$ & $\begin{array}{c}\text { Type of } \\
\text { the Bank }\end{array}$ & $\begin{array}{c}\text { License } \\
\text { Date }\end{array}$ & Website & SWIFT \\
\hline 1 & $\begin{array}{c}\text { New } \\
\text { Kabul } \\
\text { Bank }\end{array}$ & $\begin{array}{c}\text { State } \\
\text { Owned } \\
\text { Bank }\end{array}$ & $\begin{array}{c}18 \text { April } \\
2011\end{array}$ & $\begin{array}{c}\text { www.newk } \\
\text { abulbank.af }\end{array}$ & KABU AF \\
KA
\end{tabular}

Table 4: full-flagged Islamic Bank of Afghanistan ${ }^{\text {[59] }}$.

\begin{tabular}{|c|c|c|c|c|}
\hline Name of the bank & $\begin{array}{c}\text { Type of the } \\
\text { Bank }\end{array}$ & $\begin{array}{c}\text { License } \\
\text { Date }\end{array}$ & Website & SWIFT \\
\hline $\begin{array}{c}\text { Islamic Bank of } \\
\text { Afghanistan }\end{array}$ & $\begin{array}{c}\text { Private } \\
\text { Bank }\end{array}$ & $\begin{array}{c}18 \text { March, } \\
2009\end{array}$ & www.ibafg.co & 0 \\
\hline
\end{tabular}

Table 5: conventional banks of Afghanistan which do not have Islamic Banking windows.

\begin{tabular}{|c|c|c|c|c|c|}
\hline No & $\begin{array}{l}\text { Name of } \\
\text { the bank }\end{array}$ & \begin{tabular}{|c|} 
Type of \\
the Bank
\end{tabular} & License Date & Website & SWIFT \\
\hline 1 & $\begin{array}{c}\text { Pashtany } \\
\text { Bank }\end{array}$ & \begin{tabular}{|c|} 
State \\
Owned \\
Bank
\end{tabular} & $\begin{array}{c}\text { Relicensed } 26 \\
\text { June } 2004\end{array}$ & www.pashtanybank.com & $\begin{array}{c}\text { PIBA AF } \\
\text { KA }\end{array}$ \\
\hline 2 & $\begin{array}{c}\text { Afghanistan } \\
\text { International } \\
\text { Bank } \\
\end{array}$ & $\begin{array}{c}\text { Private } \\
\text { Bank }\end{array}$ & $\begin{array}{c}\text { March 22, } \\
2004\end{array}$ & www.aib.af & $\begin{array}{c}\text { AFIB AF } \\
\text { KA }\end{array}$ \\
\hline 3 & \begin{tabular}{|c|} 
The First \\
Micro \\
Finance \\
Bank \\
\end{tabular} & $\begin{array}{c}\text { Private } \\
\text { Bank }\end{array}$ & 18.March.2004 & www.fmfb.com.af & $\begin{array}{l}\text { FMFB } \\
\text { AF KA }\end{array}$ \\
\hline 4 & Azizi Bank & $\begin{array}{c}\text { Private } \\
\text { Bank }\end{array}$ & June 13, 2006 & www.azizibank.af & $\begin{array}{l}\text { AZBA } \\
\text { AF KA }\end{array}$ \\
\hline 5 & $\begin{array}{l}\text { National } \\
\text { Bank of } \\
\text { Pakistan }\end{array}$ & $\begin{array}{c}\text { Branch of } \\
\text { Foreign } \\
\text { Bank }\end{array}$ & $\begin{array}{l}\text { Permitted 1st } \\
\text { October } 2003\end{array}$ & www.nbp.com.pk & $\begin{array}{l}\text { NBPA } \\
\text { AF KA }\end{array}$ \\
\hline
\end{tabular}

\section{Conclusion}

This paper is answering one of the most important question which no one answered it until now. And the question is according to the economic politicians and anthropologists the world's economic system need an alternative and Islamic Banking is a good alternative, on the other hand, In the country in which almost all people are Muslim and 90\% of them do not use banks because of the religious orders, why Islamic Banking system is very new and young?

There are two answers for the question. First Afghanistan does not have long banking history. Second there are some factors that led to the late establishment of Islamic banking in Afghanistan firstly, because of the colonization and war, the economy of this country has not grown well enough. Secondly, the people of the country because of war remained uneducated and por. That is why they do not have any information about Banking. Thirdly, the legislative body of the government also was not strong enough to make laws or sport the Idea of Islamic Banking in Afghanistan. Fourthly, there has not been academic knowledge about Islamic Banking. That is why there are not will-educated people in the filled to work or create ideas about Islamic Banking in this country. Fifthly, because most Islamic Madrasas (schools) are in rural areas, the government does not have any control on them. These Madrasas do not have the same and modern curriculum, so the graduates of these madrasas "Ulama" do not have any information about banking system and modern societies. That is why there is no consensus among Ulama about Islamic banking sector.

\footnotetext{
${ }^{54}$ ACCI, "Afghanistan Chamber of Commerce \& Investment."

DAB, "Licensed Financial Institutions," DAB, n.d., https://dab.gov.af/Licensed-Finacial-Institutions.

${ }^{56}$ DAB, "Licensed Financial Institutions."

${ }^{57}$ DAB, "Licensed Financial Institutions."

${ }^{58}$ DAB, "Licensed Financial Institutions."
}

${ }^{59}$ DAB, "Licensed Financial Institutions.” 
Currently banking system in Afghanistan is growing especially Islamic banking. There are 12 banks are operating in Afghanistan. Seven private banks, three governmentowned banks and tow foreign banks' branches. Sex of these banks have Islamic banking windows, and one is fullfledged Islamic bank. At the end I am proposing to the related authorities some suggestions for growing and strengthening Islamic Banking and economy in Afghanistan.

\section{Proposes}

1. To the government of Islamic Republic of Afghanistan:

2. The Ministry of education should add in the curriculum of high schools some basic and general information.

3. The Ministry of Higher education must create Islamic Banking and Islamic Economics and Financial deportments in some universities.

4. The Ministry of Islamic Affairs Hajj and Endowments should order to the Imams of the mosques to provide some information about Reba and Islamic banking in their sermons (khutbas).

5. The legislative body of the government may make Islamic law and strongly sport it.

6. To Banks:

7. The Islamic Bank of Afghanistan and all of the banks which have Islamic Banking windows may publish brushers and billboards for public information.

8. To the Madrasahs:

9. The Madrasahs may change their curriculum. And add some modern sciences in curriculums.

\section{References}

1. Nezam Name Asaasi Dawlat Alaihe Afghanistan (constitution) 1340. http://catalog.acku.edu.af/cgibin/koha/opac-

detail.pl?biblionumber $=32397 \&$ query_desc $=\mathrm{kw} \% 2 \mathrm{Cwr}$ $\mathrm{d} 1 \% 3 \mathrm{~A}$

2. (BMA), Bank Meli Afghan. "Islamic Banking." BMA. Accessed 2020. https://www.bma.com.af/islamicBanking.php?i=6.

3. ACCI. "Afghanistan Chamber of Commerce \& Investment." ACCI, 1396. https://www.acci.org.af/da/home/38-news/1216-n.html.

4. ․ "Bank Dary Dar Afghanistan Da Yak Daha Wa Door Namaiaan (Banking In Afghanistan And Its Forground).” 2012. file:///E:/AFGHNBANKING/Banking Booklet (2).pdf.

5. Afganistan Bank, De. "Islamic Banking Regulations (IBR)." Da Afghanistan Bank, n.d. https://dab.gov.af/index.php/Islamic-BankingRegulations.

6. Afghan United Bank. "Islamic Banking." Afghan United bank; 2015. https://www.afghanunitedbank.com/islamic-banking/.

7. Al-Shammari, Houssein Hassan Mohamed - Ahmad, and Usama Mohammad - Abdullaah Ludeen. "The Viability of Islamic Banks Under The Current Legal Framework of Afghanistan, Djibouti, Kuwait And Sri Lanka." International Islamic Universty Malaysia, 2013. file:///C:/Users/Salim Salim/Downloads/TheViabilityofIslamicBanksunderTh ecurrentLegalFrameworkOfAfghanistanDjiboutiKuwait AndSriLanka.pdf.

8. Aliah Rejaie. "ايأين بولن سطح باسوادى در رفغانستان" Literacy Rate in Afghanistan.” BBC, 2018. https://www.bbc.com/persian/afghanistan-43563365.

9. "Aqtsad Afghanistan," n.d.

10. Ashraf U. Kazi, Abdel K. Halabi. "The Influence of Quran and Islamic Financial Transactions and Banking.” Brill 2006;20(3):12. https://about.jstor.org/terms.

11. Astfani glinski. “ مدارس دينى افغانستان بستر مناسبى براى نفوز رواعل Afghanistan's Religious Schools Are a Good Platform for Our ISIL to Infiltrate." روزنامه صبح كابل Kabul Morning Knews Paper 2020. https://subhekabul.com/مطالب_مهم/afghanistan-religiouscenters/.

12. Azhadi, Raduo. "Raduo Azhadi." Raduo Azhadi. Accessed 2020. https://da.azadiradio.com/a/27305926.html.

13. Bank, New Kabul. "Islimic Baking Overview." New Kabul Bank. Accessed 2020. http://newkabulbank.af/islamic-banking-overview.php.

14. Banking Law of Afghanistan (n.d.). https://www.kakaradvocates.com/data/laws/Law on Banking of Afghanistan - En.pdf.

15. BBC. "Afghanistan's Ghani Says 45,000 Security Personnel Killed since 2014.” BBC. Kabul, 2019. https://www.bbc.com/news/world-asia-47005558.

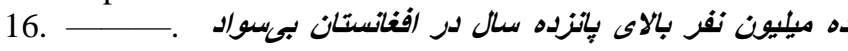
هستند' ten million people over the age of 15 in Afghanistan ate illiterate (2019). https://www.bbc.com/persian/afghanistan-49056953.

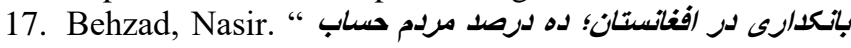
بانكس دارند $10 \%$ of the People in Afghanistan Have a Bank Account." BBC News, 2020. https://www.bbc.com/persian/afghanistan-51082747.

18. BMA. "Bank Mely Afgha (BMA)." BMA. Accessed August 7, 2020. https://www.bma.com.af/dari/abouthistory_fa.php.

19. By George Reiff, PhD. "Islamic Banking - History, Overview \& Future." DUBAI, no. By George Reiff, $\mathrm{PhD} \quad$ (n.d.). file:///C:/Users/Salim Salim/Downloads/Islamic_Banking_History_Overview _and_Fut.pdf.

20. Constitution (2004). file:///E:/AFGHN-BANKING/ قانون ساسى $1383 . p d f$.

21. DAB. "Licensed Financial Institutions." DAB, n.d. https://dab.gov.af/Licensed-Finacial-Institutions.

22. ㄴ. Regulation on Islamic Banking Liquidity Risk Management

(n.d.). https://dab.gov.af/sites/default/files/2018-

12/2RegulationonIslamicBankingLiquidityRiskManage mentAfghanistanv3finalversion2012201514164358255 3325325.pdf.

23. - Shariah Compliant Banking - National Shariah Governance Framework (Full-Fledged IFI version) (n.d.). https://dab.gov.af/sites/default/files/201812/8NSGFFFforAfghanistanFinalv3finalversion 201220 151481200553325325.pdf.

24. Daromir, Rudnyckyj. Beyond Debt, Islamic Experiments in Global Finance. Chicago: The University of Chicago Press, 2019. https://books.google.co.id/books/about/Beyond_Debt.ht $\mathrm{ml}$ ? id=3g1uDwAAQBAJ\&printsec $=$ frontcover\&source $=\mathrm{kp} \_$read_button\&redir_esc $=\mathrm{y} \# \mathrm{v}=$ onepage $\& \mathrm{q} \& \mathrm{f}=$ true.

25. De Afghanistan Bank. "Da Afghanistan Bank Issued Its First Islamic Banking License." Kabul, 2018. https://dab.gov.af/da-afghanistan-bank-issued-its-first- 
islamic-banking-license.

26. Dr. Mohammad Anwar Kohstani. Nzam Bankdari (Banking System). Kabul: Amin alectronic laibrary,

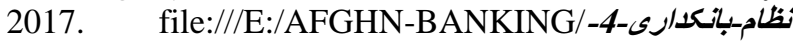
محمد_انوركوهنتانس.pdf.

27. Fofalzaie, Azizu Dean Wakili. Negahe Ba Tarikh Hsterdad Hstqlal (A Look at the History of Independence). Kabul: Menistry of knews and cultuer, n.d. http://catalog.acku.edu.af/cgi-bin/koha/opacdetail.pl?biblionumber=29139\&query_desc $=\mathrm{kw} \% 2 \mathrm{Cwr}$ d1\%3A وكيليح.

28. Frederick V, Perry JD. Ph.D., Clinical Professor of Business Law, School of Accounting, College of Business Administration, Florida International University, USA. Miami, Florida, Ph.D. Scheherazade S. Rehman, et al. "Globalization of Islamic Finance: Myth or Reality?" International Journal of Humanities and Social Science ISSN 2220-8488 (Print) 2011;1(19):2221-0989. (Online)

1.

http://www.ijhssnet.com/view.php?u=http://www.ijhssn et.com/journals/_December_2011/12.pdf.

29. Ghazanfar Bank. "Islamic Banking." Ghazanfar Bank. Accessed August 8, 2020. https://www.ghazanfarbank.com/al-wadiah-current.

30. Gllobal Banking \& Finance. "List of Islamic Banks Afghanistan." Globlal Banking \& finance. Accessed August 7, 2020. https://www.globalbankingandfinance.com/list-ofislamic-banks-afghanistan/. Habiobullah, Saeed. "Interview," 2020.

31. Haji, Amanullah. "Inreview." In Head of Resalat Travel (Haj an Umra Service Provider) Company. Kabul, n.d.

32. Hefner, Robert W. Islamizing Capitalism: On the Founding of Indonesia's First Islamic Bank. Edited by Azyumardi Azra Arskal Salim. ISEAS-Yusof Ishak institute, n.d.

33. Https://www.reference.com/history/first-bank-worldce6f0b48dce882c3. "What Was the First Bank in the World?" Accessed August 7, 2020. https://www.reference.com/history/first-bank-worldce6f0b48dce882c3.

34. Husain Sirat. “حدود بيازده ميليون افغان بيسو/دbout 11 Million Afghans Are Illirerate.” doich wila DW, 2016.

35. Islamic Bank of Afghanistan (IBA). "Profile." IBA. Accessed July 5, 2020. http://ibafg.com/home.

36. Justice, ministry of. QANON POL WA BANK DARI (money and banking) (n.d.). http://old.moj.gov.af/Content/files/OfficialGazette/0701 /OG_0770.pdf.

37. Maiwand Bank. "Maiwand Bank.” Maiwand Bank, n.d.

38. Marzia Adeel. "بانك كاسلامى' الفلاح در كابل آغاز به كار كرد" Al-Fallah Islamic Bank Opened in Kabul.” BBC Persian.com,

2006. https://www.bbc.com/persian/afghanistan/story/2006/07 /060713_s-alfalah-islamic-bank.shtml.

39. Mirghulam Mohammad ghubar. Afghanistan Dar Masir Tarikh

Kabul,

2012. https://archive.org/details/Afghanistan_in_the_course_o f_history_Ghubar/mode/2up.

40. Mohammad Haroon Amiri. "Growth and Futute of Islamic Banking in Afghanistan." coventry, 2013. file:///C:/Users/Salim

Salim/Downloads/Growth_and_Future_of_Islamic_ban king_in.pdf. Mohammadi, Abdullha. "Interviow."
Kabul, 2020.

41. Mutiara Dwi Sari1, *, Zakaria Bahari2, Zahri Hamat3. "History of Islamic Bank in Indonesia: Issues Behind Its Establishment." International Journal of Finance and Banking Research 2016;2:178-84.

42. Popal, Karim. "NAI." NAI. Kabul, 2012. http://www.kotiposti.net/msaleha/nai_10/sh_11/p_10.ht ml.professor dr. Lutfurahman Saeed. "Interview." n.d.

43. Rudnyckyj, Daromir. Beyond Debt Islamic Experiments in Global Finance. Chicago 60637: The University of Chicago Press, Chicago 60637, 2019. file://C:/Users/Salim Salim/Downloads/Beyond Debt_Islamic Experiments in Global Finance_Daromir Rudnyckyj.pdf.

44. "Sair Tarikhi Qanone Asaasi Afghaniatan (History of Constitution of Afghanistan)." Accessed July 5, 2020. http://www.afghangerman.net/upload/elmi_bibliothek/history_afg_constit utions_dari.pdf.

45. Samangani, AliAkbar Sdiqi. "Bankdari Bedoon Reba (Don Yosury Banking)." 8 Subh. n.d. https://8am.af/بانكد/رى-بلون-ريا-در-ففانستان/2.

46. SDiqi, Abdulwali. "Az Amanullahta HmedKarzay." Shabake Atlaa Rasani Afghanistan (Afghanpaper.Com, no. shabake Atlaa rasani Afghanistan (Afghanpaper.com (1392). http://www.afghanpaper.com/nbody.php?id=63679.

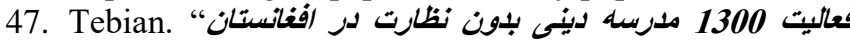
Activities of 1300 Unattended Religious Schools in Afghanistan." tebian, N.d.

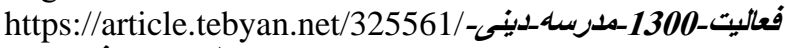
بدون-نظارت_ر-فغانستان

48. Tobin, Sarah A. Everyday Piety Islam And Economy In Jordan. Ithaca and London: Cornell University Press, 2016.

49. VOA. "جمعيت باسواد در افغانستان به برhe Literari Popuation in Afghanistan Reached 42\%." VOA, n.d. https://www.darivoa.com/a/literacy-level-inAfghanistan-rose-to-42-percent/5074717.html.

50. Wadsam. "Islamic Bank of Afghanistan to Open as Country's First Fully-Fledged Islamic Bank." Afghan Business News Portal. April 24, 2018. https://wadsam.com/afghan-business-news/islamicbank-afghanistan-open-countrys-first-fully-fledgedislamic-bank-232/.

جايكاه افغانستان در رتبهبندى شاخصهاى كسب و كار بانك " $\boldsymbol{8}$ "Subh. 1396. Sartan. 